\title{
EFFECT OF DIFFERENT FEEDING PROGRAM AT FIRST DAY ON PERFORMANCEAND ECONOMIC INDEX OF BROILER CHICKENS
}

\author{
SHAHLA. M.S. KIRKUKI \\ Animal Production Department, Faculty of Agricultural Sciences, Sulaimani University, Sulaimani, KGR, Iraq.
}

Received: 31 December 2015; Accepted: 26 January 2016

\begin{abstract}
A total of 132 one day old Ross (308) broiler chickens were used to determine the effect of four treatments (feed program) on broiler performance and economic index. At delivery the chicks were weighted. As well as, the body weight, weight gain, feed intake, feed conversion ratio was recorded at day 14, 21, 28, 35 and 42. Economic index was recorded at 42. Four treatments includes: feeding immediately after delivery in the hatchery and continue to the farm (T1); fasting for 12 hours after hatch with access to water (T2); fasting for 12 hours with access to water containing 5\% sugar followed by feeding the diet (T3); or feeding a diet immediately at the farm (T4). Interaction between treatments and different periods, were significantly $(\mathrm{p}<0.05)$ effected on body weight, although, the effect of treatments at each period did not significant. Overall of body weight/ period was significantly $(\mathrm{p}<0.05)$ higher at day 42 followed by the least periods. Significant $(\mathrm{p}<0.05)$ effect of interaction between treatments with periods, treatments and periods were observed in feed intake and weight gain. Feed conversion ratio did not significantly affected by different periods. Economic index did not significantly affected by different treatments. Values of economic index were numerally influenced of: body weight, body weight gain, feed intake, viability\% and feed conversion ratio.
\end{abstract}

Key words: Feeding program, first day old, broiler, economic index, performance.

\section{INTRODUCTION}

During the last few decades, because of undergone intensive genetic selection of broiler chickens for better growth performance (Shariatmadari, 2012). The number of days required to reach market weight continues to decline, and the first few days of life have become a greater portion of the whole life cycle of the broiler (Wang, 2014). Which, make the getting the birds off to a good start more importance. Early access to feed can provide advantages to growth that continue for up to 35 days post hatch (Bhanja et al., 2010).

The importance of strategies of nutrition and feeding during the starter stage was increased. During commercial production of poultry, over 24 - 48 hours or may be for up to 72 hours holding period may occur before they reach farms, or prior to access to feed (Noy and Sklan 1998; Willemsen et al., 2010; Abed et al., 2011). The time of deprivation of chicks may increase when the distance to farm was very far.

Corresponding author: Dr. SHAHLA. M.S. KIRKUKI

E-mail address: shahlan26@gmail.com

Present address: Animal Production Department, Faculty of Agricultural Sciences, Sulaimani University, Sulaimani, KGR, Iraq.
These chicken do not have access to feed or/and water, so the body weight decreased and intestine and muscle developments of bird are reduced (Sklan et al., 2000; Peebles et al., 2005; Noy and Uni, 2010). Other studies have been conducted to evaluate the effect of delay in access to feed for newly hatched chickens on broiler growth performance (Nir and Levanon 1993; Noy and Sklan, 1999; Bigot et al., 2003; Berri et al., 2007). While, Juul - Madsen et al. (2004), Vargas et al. (2009) and Rammouz et al. (2011) found that post hatching delay in feed access did not affect chicken body weight at market age. ElHusseiny et al. (2008) indicated that a decrease in body weight gains and higher feed to gain ratio, resulting from holding chicks without feed, continued to affect chicks up to 6 weeks post hatch.

Studies have found that the active transport system for glucose and fructose start developing 1 hour after feeding sucrose to 1 day old chicks (Sheshukova and Ozols 1986) and the mucosa responded to the adaptive changes in sucrase activity (Ozols and Sheshukova, 1985). Glucose, sucrose and glycerol may have potential to increase chicken performance. Glucose and sucrose are mono and disaccharide carbohydrates and can be easy utilized by chickens. Earlier research found that chicks acquire more energy from a glucose based diet than a corn based 
diet until day 21 post hatch (Batal and Parsons, 2002). However, Sorbara et al. (2006) found that using glucose and sucrose to replace starch as the energy source improved chick growth performance during the first 7 days post hatch. Providing nutrients early is important because newly hatched chicks have active satellite cells, responsible for muscle growth, that benefit from early access to nutrients. Feed restriction at an early age resulted in inhibition of satellite cell proliferation and differentiation (Yue et al., 2012).

Determining the poultry production profitability is essential for the farmers' economic progress, and may contribute for the development of public and private policies (Mendes et al., 2014). One of the most convenient measures of success is profitability of production, because it is observable and it is not subject to interpretation (Duffy and Nanhou, 2003). Economic European Production Efficiency Factor is used in many countries of the world as a tool for measuring growing performances to broiler chicken (Van, 2003). Therefore, the factors involved in the European Production Efficiency Factor are body weight gain, feed conversion ratio and viability and are considered universal measures for evaluating broilers performance (Marcu et al., 2013). The European Production Efficiency Factor was used for expressing production efficiency in a single index. European Production Efficiency Factor is used to express the overall production profile (Perić et al., 2009; Nabizadeh, 2012).

This study presents a part of the trial that aimed to estimate the productive performance and economic effects of feeding program at first day of chicken's broilers.

\section{MATERIALS AND METHODS}

A total of 132one day-old Ross 308 broiler chicks were allocated randomly to four treatments having three replicates with constituted 33 chicks per treatments. The four treatments (feeding program) include; feeding immediately after delivery in the hatchery and continue to the farm (T1), fasting for 12 hours after hatch with access to water (T2), fasting for 12 hours with access to water containing 5\% sugar followed by feeding the diet (T3), or feeding a diet immediately at the farm (T4). Commercial feed $(\mathrm{CP}=$ $22.0 \%$ and $\mathrm{ME}=3,100 \mathrm{kcal} / \mathrm{kg}$ ) was used as a starter for feeding from 1 to 3 week of age and another feed $(\mathrm{CP}=18.0 \%$ and $\mathrm{ME}=3,200 \mathrm{kcal} / \mathrm{kg})$ as a finisher from 4 to 6 week of age. Feed and water were consumed ad libitum except at day 7-14. Compensatory growth normally is induced by feed restriction during day 7-14 of age was used by decreasing light to 16 hour as described by (Leeson and Summers (2001).

At delivery chicks were weighing for each treatments, and performance parameters investigated during the experimental periods were: body weight, average daily weight gain, feed conversion ratio, the mortality, for each periods $(14,21,28,35$ and 42) days old age, as well as the economic efficiency of growth, through the calculation of European Production Efficiency Factors and European Broiler Index were at day 42 .

For analysis of performance indicators such as: body weight gain, average daily gain, feed conversion ratio, viability, European Production Efficiency Factors and European Broiler Index the following formulas were used:

Body weight gain (grams on period) $=$ Body weight $(\mathrm{g})$ at the end period - Body weight $(\mathrm{g})$ in first day

Average daily gain $(\mathrm{g} / \mathrm{chick} / \mathrm{d})=$ Body weight Gain/ days number of growth period

FCR (kg feed/kg gain) = cumulative feed intake $(\mathrm{kg}) /$ total weight gain $(\mathrm{kg})$

Viability $(\%)=$ chicks remaining at the end of period (\%)

European Production Efficiency Factors = [Viability (\%) $\mathrm{x}$ Body weight (kg)]/ [age (day) x Feed conversion ratio] $\mathrm{x} 100$

European Broiler Index $=$ [Viability $(\%) \mathrm{x}$ Average daily gain (g/chick/d)]/ [Feed conversion ratio x 10].

\section{Statistical Analysis}

The analysis of variance was done for all recorded Data to find out the differences between treatments, periods and their interaction by Statistical Program PASW Statistics Student Version 18 SPSS. An ANOVA using the general linear models procedure included the main effects of treatments, periods and their interaction broiler performance. Duncan Multiple Range Test (Duncan, 1955) was used to test the significant differences between the means of the levels.

\section{RESULTS}

Although, the effect of interaction between treatments and different periods was significant $(\mathrm{p}<0.05)$ as showed in (Table 1), the effect of treatments on live body weight at each period was not significant. In spite of these results, the differences were numerically. The highest body weight was obtained by birds in T1 at age 14, 21 and 28 day, while T4 followed by $\mathrm{T} 1$ delivered the highest value of body weight at age 35 and 42 day. Furthermore, body weight of birds in $\mathrm{T} 3$, higher than $\mathrm{T} 2$ about $(89 \mathrm{~g})$. Effect of periods on body weight was significant $(\mathrm{p}<0.05)$, normally the body weight at day 42 $(2891.63 \mathrm{~g})$ significantly $(\mathrm{p}<0.05)$ had the highest mean followed by least ages $(35,28,21,14$ and 1) day (2133.00, 1433.63, 384.33.192.17 and 39.04g), respectively. 
Table 1: Effect of interaction of treatments and different periods and periods on live body weight (g).

\begin{tabular}{|c|c|c|c|c|c|c|}
\hline \multirow{3}{*}{ Treatment* } & \multicolumn{6}{|c|}{ Live body weight $(\mathrm{g})$. } \\
\hline & \multicolumn{6}{|c|}{ Periods (day) } \\
\hline & 1 & 14 & 21 & 28 & 35 & 42 \\
\hline $\mathrm{T} 1$ & $39.33^{\mathrm{e}}$ & $203.33^{\mathrm{de}}$ & $406.67^{\mathrm{d}}$ & $1531.17^{\mathrm{c}}$ & $2110.83^{b}$ & $2903.33^{\mathrm{a}}$ \\
\hline $\mathrm{T} 2$ & $38.33^{\mathrm{e}}$ & $186.67^{\mathrm{de}}$ & $373.33^{\mathrm{d}}$ & $1417.67^{\mathrm{c}}$ & $2063.83^{b}$ & $2804.17^{\mathrm{a}}$ \\
\hline $\mathrm{T} 3$ & $39.00^{\mathrm{e}}$ & $185.33^{\mathrm{de}}$ & $370.67^{\mathrm{d}}$ & $1380.00^{\mathrm{c}}$ & $2084.67^{\mathrm{b}}$ & $2893.67^{\mathrm{a}}$ \\
\hline $\mathrm{T} 4$ & $39.50^{\mathrm{e}}$ & $193.33^{\mathrm{de}}$ & $386.67^{\mathrm{d}}$ & $1405.67^{\mathrm{c}}$ & $2272.67^{b}$ & $2965.33^{\mathrm{a}}$ \\
\hline Overall mean/ Period & $39.04^{\mathrm{f}}$ & $192.17^{\mathrm{e}}$ & $384.33^{\mathrm{d}}$ & $1433.63^{\mathrm{c}}$ & $2133.00^{\mathrm{b}}$ & $2891.63^{\mathrm{a}}$ \\
\hline Mean \pm Std. Error & \multicolumn{6}{|c|}{$1178.97 \pm 16.71$} \\
\hline
\end{tabular}

Results in (Table 2) showed although, there was no significant differences between treatments at different periods, there was an oscillatory in feed intake, likewise T1 and T4 intake numerically higher than T2 and $\mathrm{T} 3$ at day 14 and 21 . Furthermore, birds in $\mathrm{T} 3$ followed by $\mathrm{T} 2$ at day 28 numerically intake the bigger amount of feed compared with other treatments, while T4 intake highest amount of feed intake at day 35 and $\mathrm{T} 1$ return to overcome the other treatments at day 42. However the birds at $\mathrm{T} 4$ significantly $(\mathrm{p}<0.05)$ intake higher amount of feed $(5440.61 \mathrm{~g})$ of overall means, followed by T1, T2 and T3 (5385.59, 5132.73 and 5076.11g), respectively.

Table 2: Effect of interaction of treatments and different periods, overall means/ treatment of treatments and overall/ period on feed intake ( $\mathrm{g} / \mathrm{bird}$ ).

\begin{tabular}{|c|c|c|c|c|c|c|}
\hline \multirow{3}{*}{ Treatment } & \multicolumn{5}{|c|}{ Feed intake (g/bird) } & $\begin{array}{c}\text { Overall Mean/ } \\
\text { Treatment }\end{array}$ \\
\hline & \multicolumn{6}{|c|}{ Periods (day) } \\
\hline & $1-14$ & $15-21$ & $22-28$ & $29-35$ & $36-42$ & $1-42$ \\
\hline $\mathrm{T} 1$ & $247.12^{\mathrm{e}}$ & $416.67^{\mathrm{e}}$ & $1810.61^{\mathrm{abc}}$ & $1301.52^{\mathrm{cd}}$ & $1609.67^{\text {abcd }}$ & $5385.59^{\mathrm{ab}}$ \\
\hline $\mathrm{T} 2$ & $224.09^{\mathrm{e}}$ & $296.97 \mathrm{e}$ & $1937.88^{\mathrm{ab}}$ & $1259.09^{\mathrm{cd}}$ & $1414.70^{\text {bcd }}$ & $5132.73^{\mathrm{bc}}$ \\
\hline T3 & $220.67^{\mathrm{e}}$ & $248.49 \mathrm{e}$ & $2089.39^{\mathrm{a}}$ & $1146.06^{\mathrm{d}}$ & $1371.50^{\text {bcd }}$ & $5076.11^{\mathrm{c}}$ \\
\hline $\mathrm{T} 4$ & $244.15^{\mathrm{e}}$ & $359.09^{\mathrm{e}}$ & $1833.33^{\mathrm{abc}}$ & $1590.91^{\text {abcd }}$ & $1413.13^{\text {bcd }}$ & $5440.61^{\mathrm{a}}$ \\
\hline $\begin{array}{l}\text { Overall mean/ } \\
\text { Period }\end{array}$ & $236.03^{\mathrm{d}}$ & $330.30^{\mathrm{e}}$ & $1917.80^{\mathrm{a}}$ & $1324.39^{\mathrm{c}}$ & $1452.25^{\mathrm{d}}$ & \\
\hline $\begin{array}{l}\text { Mean } \pm \text { Std. } \\
\text { Error }\end{array}$ & \multicolumn{5}{|c|}{$1051.75 \pm 93.14$} & $\begin{array}{c}5258.76 \pm \\
552.25\end{array}$ \\
\hline \multicolumn{7}{|c|}{$\begin{array}{l}\text { a- }-\mathrm{e} \text { interaction means of different letters differ significantly }(\mathrm{P}<0.05) \text {. } \\
\mathrm{a}-\mathrm{e} \text { overall of Body Weight }(\mathrm{g}) / \text { Period means of different letters differ significantly }(\mathrm{P}<0.05) \text {. } \\
\mathrm{a}-\mathrm{c} \text { overall of Body Weight }(\mathrm{g}) / \text { treatment means of different letters differ significantly }(\mathrm{P}<0.05) \text {. } \\
*(\mathrm{~T} 1) \text { : feeding immediately after delivery in the hatchery and continue to the farm; }(\mathrm{T} 2) \text { : fasting for } 12 \text { hours after hatch with } \\
\text { access to water; (T3): fasting for } 12 \text { hours with access to water containing } 5 \% \text { sugar followed by feeding the diet or }(\mathrm{T} 4) \text { : } \\
\text { feeding a diet immediately at the farm. }\end{array}$} \\
\hline
\end{tabular}

The effect of interaction between treatments with periods, treatments and different periods on body weight gain was significant $(\mathrm{p}<0.05)($ Table 3$)$. The highest value of body weight gain at day 28 attributed to higher amount of feed intake at this period. At the end of experimental the difference between treatments was significant $(\mathrm{p}<0.05)$, birds in $\mathrm{T} 4$ obtained significantly $(\mathrm{p}<0.05)$ higher weight gain (2925.83g) than birds in T2 $(2765.83 \mathrm{~g})$, but did not significantly differed with T1 and T3 (2864.33 and $2854.33 \mathrm{~g}$ ), respectively. Furthermore, the effect of different periods was significant $(\mathrm{p}<0.05)$, at day 28 birds generally had the highest value of weight gain (1049.29g) compared with the followed periods day 35 and 42 (699.38 and 758.63g), respectively. 
Table 3: Effect of interaction of treatments and different periods on body weight gain $(\mathrm{g})$.

\begin{tabular}{|c|c|c|c|c|c|c|}
\hline \multirow{3}{*}{ Treatment } & \multicolumn{5}{|c|}{ Body weight gain (g) } & $\begin{array}{c}\text { Overall mean/ } \\
\text { Treatment }\end{array}$ \\
\hline & \multicolumn{6}{|c|}{ Periods (day) } \\
\hline & $1-14$ & $15-21$ & $22-28$ & $29-35$ & $36-42$ & $1-42$ \\
\hline $\mathrm{T} 1$ & $146.33^{\mathrm{e}}$ & $185.33^{\mathrm{e}}$ & $1009.33^{\text {abc }}$ & $704.67^{\text {bcd }}$ & $818.67^{\text {abcd }}$ & $2864.33^{\mathrm{ab}}$ \\
\hline $\mathrm{T} 2$ & $148.33^{\mathrm{e}}$ & $186.67^{\mathrm{e}}$ & $1044.33^{\mathrm{ab}}$ & $646.17^{\mathrm{d}}$ & $740.33^{\text {bcd }}$ & $2765.83^{b}$ \\
\hline $\mathrm{T} 3$ & $164.00^{\mathrm{e}}$ & $203.33^{\mathrm{e}}$ & $1124.50 \mathrm{a}$ & $579.67^{\mathrm{d}}$ & $782.83^{\text {bcd }}$ & $2854.33^{\mathrm{ab}}$ \\
\hline T4 & $153.83^{\mathrm{e}}$ & $193.33^{\mathrm{e}}$ & $1019.00^{\mathrm{abc}}$ & $867.00^{\mathrm{abcd}}$ & $692.67^{\mathrm{cd}}$ & $2925.83^{a}$ \\
\hline $\begin{array}{l}\text { Overall mean/ } \\
\text { Period }\end{array}$ & $153.13^{c}$ & $192.17^{c}$ & $1049.29^{\mathrm{a}}$ & $699.38^{b}$ & $758.63^{\mathrm{b}}$ & ----------- \\
\hline \multicolumn{3}{|l|}{ Mean \pm Std. Error } & \multicolumn{3}{|c|}{$570.52 \pm 49.466$} & $2852.59 \pm 205.25$ \\
\hline \multicolumn{7}{|c|}{ 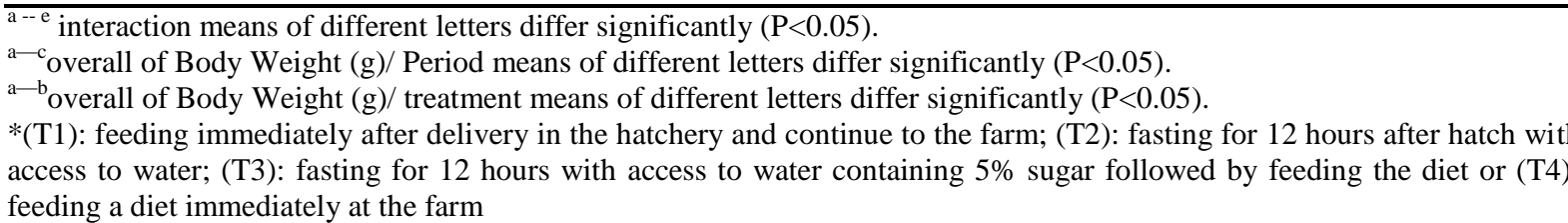 } \\
\hline
\end{tabular}

The effect of interaction between treatments and different periods was significant $(\mathrm{p}<0.05)$ on feed conversion ratio (Table 4 ). The $\mathrm{T} 1$ at day 21 had the highest value of feed conversion ratio (2.28) compared with other treatments at all different periods. In addition, the T3of overall means (1-42) day had significantly $(\mathrm{p}<0.05)$ the better value of feed conversion ratio (1.86) compared with $\mathrm{T} 1$ (2.01). Concerning the overall of feed conversion ratio for different periods the differences were not significant. However, at day 28 birds had the better feed conversion ratio (1.85).

Table 4: Effect of interaction of treatments and different periods, treatments and periods on feed conversion ratio.

\begin{tabular}{|c|c|c|c|c|c|c|}
\hline \multirow{3}{*}{ Treatment } & \multicolumn{5}{|c|}{ Feed conversion ratio } & \multirow[t]{2}{*}{$\begin{array}{c}\text { Overall mean/ } \\
\text { Treatment }\end{array}$} \\
\hline & \multicolumn{5}{|c|}{ Periods (day) } & \\
\hline & $1-14$ & $15-21$ & $22-28$ & $29-35$ & $36-42$ & $1-42$ \\
\hline $\mathrm{T} 1$ & $2.05^{\mathrm{ab}}$ & $2.28^{\mathrm{a}}$ & $1.86^{\mathrm{b}}$ & $1.85^{\mathrm{b}}$ & $1.99^{\mathrm{ab}}$ & $2.01^{\mathrm{a}}$ \\
\hline $\mathrm{T} 2$ & $1.85^{\mathrm{b}}$ & $1.88^{\mathrm{b}}$ & $1.86^{\mathrm{b}}$ & $1.94^{\mathrm{b}}$ & $1.94^{\mathrm{b}}$ & $1.89^{\mathrm{ab}}$ \\
\hline $\mathrm{T} 3$ & $1.83^{\mathrm{b}}$ & $1.82^{\mathrm{b}}$ & $1.86^{\mathrm{b}}$ & $2.00^{\mathrm{ab}}$ & $1.80^{b}$ & $1.86^{\mathrm{b}}$ \\
\hline $\mathrm{T} 4$ & $1.91^{\mathrm{b}}$ & $1.92^{\mathrm{b}}$ & $1.80^{\mathrm{b}}$ & $1.84^{\mathrm{b}}$ & $2.08^{\mathrm{ab}}$ & $1.91^{\mathrm{ab}}$ \\
\hline $\begin{array}{l}\text { Overall mean/ } \\
\text { Period }\end{array}$ & 1.91 & 1.98 & 1.85 & 1.910 & 1.95 & --------- \\
\hline $\begin{array}{l}\text { Mean } \pm \text { Std. } \\
\text { Error }\end{array}$ & \multicolumn{5}{|c|}{$1.919 \pm 0.02$} & $1.86 \pm 0.06$ \\
\hline
\end{tabular}

There is no significant effect of different treatments on Viability (\%), European Production Efficiency Factors and European Broiler Index at day (42) of old (Table 3).

The higher values was recorded in broilers from T4 for European Production Efficiency Factor (369.65) and European Broiler Index (255.31), followed by broilers from T3 for European Production Efficiency Factor (365.03) and European Broiler Index (253.13) and T2 for European Production Efficiency Factor (353.26) and European Broiler Index (243.90) and the values of European Production Efficiency Factor (341.47) and European Broiler Index (238.74) was 
obtained by birds in T1. However, chickens in the T1 were lower than T4 and T3 with up to (8.25 and 6.90 $\%)$, respectively for European Production Efficiency Factor and with up to $(6.94$ and $6.03 \%)$, respectively for European Broiler Index. Increasing values of the two indices (European Production Efficiency Factor and European Broiler Index) at T4 chicks, shows that the performances obtained are better than to the $\mathrm{T} 1$, T2 and T3 chicks. The economic efficiency assessment on European Production Efficiency Factor and European Broiler Index was positively influenced by the growth performances, body weight, average daily gain, feed conversion ratio and recorded viability for boiler.

Table 3: Effect of feeding programat first day on Viability (\%), European Production Efficiency Factors and European Broiler Index at day 42 of old.

\begin{tabular}{|c|c|c|c|}
\hline Treatments* & Viability (\%) & $\begin{array}{l}\text { European } \\
\text { Efficiency Factors }\end{array}$ & European Broiler Index \\
\hline $\mathrm{T} 1$ & 99.33 & 341.47 & 238.74 \\
\hline $\mathrm{T} 2$ & 100.00 & 353.26 & 243.90 \\
\hline $\mathrm{T} 3$ & 98.33 & 365.03 & 253.13 \\
\hline $\mathrm{T} 4$ & 100.00 & 369.65 & 255.31 \\
\hline Mean \pm Std. Error & $99.42 \pm 1.5$ & $357.35 \pm 34.29$ & $247.77 \pm 24.17$ \\
\hline
\end{tabular}

*(T1): feeding immediately after delivery in the hatchery and continue to the farm; (T2): fasting for 12 hours after hatch with access to water; (T3): fasting for 12 hours with access to water containing 5\% sugar followed by feeding the diet or (T4): feeding a diet immediately at the farm.

\section{DISCUSSION}

Results in (Table 1) showed the significant $(\mathrm{p}<0.05)$ effect of interaction between treatments and different periods on body weight, in spite of the significant differences of interaction, the effect on body weight of treatments at each period numerically. Whereas, the birds which had the highest body weight were obtained by birds in T1 at age 14, 21 and 28 day numerically, while $\mathrm{T} 4$ followed by $\mathrm{T} 1$ delivered the highest value of body weight at age 35 and 42 day, in addition of the T3 higher than T2 about $(89 \mathrm{~g})$. These may be due to chick in $\mathrm{T} 1$ and $\mathrm{T} 4$ as well as $\mathrm{T} 3$ compared with $\mathrm{T} 2$ (fasting without any additional) did not be exposed to energy deficit by nutritional and sugar supplies. The effect of fasting, delayed and deprivation of feed for different periods at the early days of age were discussed by previous literatures. Likewise, Dibner et al. (1998) how reported that without additional nutritional supplies in the first 24 hours, the chicks are clearly in energy deficit and will invariably lose weight. Noy and Sklan (1999) providing water immediately post hatch resulted in heavier chicks compared with chicks that had delayed accessed to feed until 8 days age. Early access to feed can provide advantages to growth that continue for up to 35 days post hatch (Bhanja et al., 2010). Bigot et al. (2003) found feed deprivation for 48 hours post hatch caused a $(7 \%)$ loss in body weight while body weight increased by $(36 \%)$ for early fed chicks. The results at day 42 in this study was supported by Rammouz et al. (2011) who reported that a 6 to 12 hour post hatching delay in feed access did not affect chicken body weight at market age. Vargas et al. (2009) found that 12 hours feed delay at hatch and did not affect other growth performance throughout the trial. Juul-Madsen et al. (2004) found that by delaying access to feed for 24 hours after hatching did not have impact on body weight at market age. Also they reported that early fed chickens were $(6.1 \%)$ heavier at market age than those with a 48 hour delay in access to feed. While, Abed et al. (2011) found that body weight at market age was lower for the group with a 48 hour delay but the chicks from the 16 and 32 hour feed delay weighed the same. Also they found 16 and 32 hour feed delay had negative effects on body weight until the birds were 21 days old compared to chicken which had immediate access to feed, and by day 28 and 35 post hatch, there was no longer a difference in body weight. Cengiz et al. (2012) found that broiler chicks were subjected to 36 hours post hatch delayed access to feed and water, body weight and feed consumption reduced during first 4 weeks of the production cycle. Hooshmand (2006) found significant $(\mathrm{p}<0.05)$ effect of feeding program when use starter diet immediately after hatch, restarted, fasting, and sugar corn feeding programs. Saki (2005) reported that body weight was decreased by chickens, which were not accessed to feed compared to that group which was fed by starter diet immediately after hatching. Although, the difference of body weight between T2 $(2804.17 \mathrm{~g})$ and T3 (2893.67g) not significant, the differences was numerically, this result may be attributed to 
supplementation of sugar, which consider as resource of energy and potential to increase chicken performance and can be easy utilized by chickens (Batal and Parsons, 2002; Sorbara et al., 2006; Wang, 2014).

Results in (Table 2) showed significant $(\mathrm{p}<0.05)$ effect of interaction between treatments and different periods, although there was no significant differences between treatments at different periods, as well as there were an oscillatory in feed intake, likewise T1 and T4 intake numerically higher than $\mathrm{T} 2$ and $\mathrm{T} 3$ at day 14 and 21 . These may be attributed to that chicks in these treatments exposed to early feed had the faster development of the digestive system. The finding of lower weight gain in fasted chicks during the first week of life is consistent with reports by Batal and Parsons (2002) and Boersma et al. (2003). Lower weight gain in fasted groups could be attributed to lower feed intake and poor development of digestive tract. Most of the energy and nutrients consumed by birds <4 weeks goes toward growth (Tabler, 2008). These results were supported by previous studding. Murakami et al. (1992) reported that daily feed intake increased linearly for 15 days post-hatch the fed chicks. Ullah et al. (2012) reported that chicksin early age, the development of the digestive system is much faster than the rest of the body which. The length and weight of the digestive system significantly increase in the first week of life (Nitsan et al., 1991a). Nitsan et al. (1991b) reported that digestion and absorption of nutrients early in life depends primarily on pancreatic enzyme activity, which in the chick is weak at hatch.

Feed intake stimulate these secretions dramatically which are noticed in the first week of life. Furthermore, birds in T3 followed by $\mathrm{T} 2$ at day 28 numerically intake the bigger amount of feed compared with other treatments, while T4intake highest amount of feed intake at day 35 and T1 return to overcome the other treatments at day 42 . However the birds at T4 significantly $(\mathrm{p}<0.05)$ intake higher amount of feed $(5440.61 \mathrm{~g})$ of overall means, followed by $\mathrm{T} 1, \mathrm{~T} 2$ and $\mathrm{T} 3(5385.59,5132.73$ and $5076.11 \mathrm{~g})$, respectively. The birds at day 28 intake significantly $(\mathrm{p}<0.05)$ highest amount of overall mean feed compared with other periods (Table 2). This may be due to end of the compensatory growth program of birds at day 21 , and birds return to continue feeding to compensatory growth after favorable conditions are provided again. However, feed intake during the first days post hatch as well as over the whole production cycle was improved by early access to feed. Zubair and Leeson (1996) reported that the animals can exhibit an accelerated growth rate that will reduce the difference between these individuals with initially reduced growth rate and individuals with normal growth rate. The overall advantages throughout the production period may provide by compensatory growth (Wang, 2014). However, Abed et al. (2011) found that the feed intake during the first 10 days post hatch as well as over the whole production cycle was improved by early access to feed. Mohebodini et al. (2009) reported a decrease in feed intake of broiler chickens as a result of feed restriction. While, Hooshmand (2006) observed no significant differences in overall feed intake. The sucrose based and starch based control diets did not affect feed intake (Batal and Parson, 2004). Also, Leeson and Summers (2001) and Jiang et al. (2008) reported that the feed intake was reduced by providing glucose to newly hatched birds. Tabedian et al. (2010) found Feed intake was not different for the experimental groups at 7-21 days of age for fasting 24 hour and controlfeed intake appeared to be only slight immediately posthatch; intake increased with time resulting in body weight increases after digestion and metabolism of the ingested feed (Sklan et al., 2000). Vargas et al. (2009) found that a 12 hours feed delay at hatch only had a negative effect on feed intake during first 10 days post hatch.

It is observation that the effect of interaction of treatments and periods on weight gain significant $(\mathrm{p}<0.05)$ (Table 3). At Furthermore, the overall mean of weight gain at day 28 was significantly $(p<0.05)$ higher than the means in the other periods. This attributed to the significant $(\mathrm{p}<0.05)$ higher feed intake at this period. However, the effect of treatments on overall means of body weight was also significant $(p<0.05)$, birds in T4 obtained significantly $(\mathrm{p}<0.05)$ higher weight gain than birds in $\mathrm{T} 2$, but did not significantly differed with $\mathrm{T} 1$ and T3. Results in this study were supported by Murakami et al. (1992) reported that rapid growth during 14 days after hatch was observed in the fed chicks. Also, Noy and Sklan (1999) reported that the chicken growth rate was affected by delayed feed access. If feed is provided early, chicks can gain around $(11 \mathrm{~g})$ body weight during first 2 days post hatch (Mahmoud and Edens. 2012). The reason was summarized by Bigot et al. (2003) who reported that muscle development corresponds with the time between hatch and availability of feed. Sklan et al. (2000) reported that when chicks leave the hatchery they are 3 grams heavier on average than unfed birds. And at day 21 post hatch, these chicks were still heavier than chicks that were not fed until placement. Lower weight gain in fasted chicks in first week is in agreement with those of (Batal and Parsons, 2002). This resultcould be attributed to lower feed intake and poor development of digestive tract (Tabeidian et al., 2011). May be because of, the important of feed intake in the youngest birds. Most of the energy and nutrients consumed by birds younger than four weeks goes toward growth (Tabler, 2008). This means that if nutrients are restricted early in the bird's life, it reduce the bird performance (Tabeidian et al., 2011). When feed consumption starts soon after hatch, the nutrients provided by the feed are complementary to 
the yolk nutrients (Murakami et al., 1992). Initiation of feed consumption as close to hatch as possible is necessary to support early muscle development, which may ultimately affect meat yield (Tabeidian et al., 2011). Muscle development is seriously compromised when feed is withheld during the first few days after hatch and feeding the semisolid diet containing the egg powder and glucose syrup for 48 hours resulted to higher weight gain in birds. This could be related to higher feed intake in this group (Table 2). In this study, increasing the energy of early diet by feeding glucose syrup in a semi-solid diet did not result to higher post hatch performance which may be due to immaturity of digestive enzyme secretion. This may occur because glucose is absorbed with no additional enzymatic activity, which yields no stimulation of intestinal processes. These results in consist with El-Husseiny et al. (2008) who indicated that a decrease in body weight gains and higher feed to gain ratio, resulting from holding chicks without feed, continued to affect chicks up to 6 weeks post hatch. The overall FCR was not affected by delay in first feeding (Abed et al., 2011). Wei et al. (1984) reported that sucrose and glucose fed chicks did not show significant differences in weight gain. Jiang et al. (2008) indicated that providing an $8 \%$ glucose solution did not affect chick weight gain during day 3 to day 10 post hatches. (Cengiz et al., 2012). The chicken growth rate was affected by delayed feed access.

The interaction effect of treatments ant different periods on feed conversion ratio were significant $(\mathrm{p}<0.05)$. Birds in $\mathrm{T} 1$ had significantly $(\mathrm{p}<0.05)$ lower feed conversion ratio compared with other treatments at day 21 . Feed to gain ratio for the first 10 days post hatch was suppressed by a 48 hours delay in access to feed but not for other delay times (Abed et al., 2011). During the first week of access to feed and water, the birds expressed the lowest feed to gain ratio than any other period (Wang, 2014). Furthermore, effect of treatment also significant $(\mathrm{p}<0.05)$. Birds inT2 had the better feed conversion ratio followed by $\mathrm{T} 3$, while the differences of feed conversion ratio at different periods were not significant. These results indicated that although the body weight and weight gain of treatments which received feed immediately were high the treatments with delay feeding reached to high conversion ratio at marketing age. These results were supported by Hooshmand (2006) who found the feed conversion ratio was better of fasting groups compared with other groups. Also they found no interactions and overall were observed between feeding program and supplement in feed conversion ratio. Also, Tabedian et al. (2010) found no significant differences in feed conversion ratios occurred among the treatment diet groups and after first week, no significant differences in feed conversion ratios occurred among the treatment diet groups. Also these finding are in agreement with research of Noy and Sklan (1999),
Batal and Parsons (2002) and Saki (2005). While, Murakami et al. (1992) reported that increase of daily feed intake for post-hatch the fed chicks resulted in a high efficiency (80\%) of feed utilization. Wei et al. (1984) reported that sucrose and glucose treated chicks did not show a significant differences in weight gain and feed conversion ratio. Batal and Parson (2004) reported that glucose based diets resulted in a better feed to gain ratio than sucrose based and starch based diets. An earlier study reported that $5 \%$ dietary glucose or sucrose did not affect chicken feed to gain ratio (Wei et al., 1984).

Although, the differences between treatments were not significant of economic index (Table 5). The higher values were obtained by birds in T4 (369.65 and 255.31) for European Production Efficiency Factor and European Broiler Index, respectively. However, chickens in the T1 were lower than T4 and T3 with up to $(8.25$ and $6.90 \%)$ and $(6.94$ and 6.03 $\%)$, for European Production Efficiency Factor and European Broiler Index, respectively. Increasing values of the two indices (European Production Efficiency Factor and European Broiler Index) at T4 chicks, shows that the performances obtained are better than to the T1, T2 and T3 chicks. The lower value of economic index in $\mathrm{T} 1$ may be attributed to lower viability $\%$ and high feed intake and lower feed conversion ratio compare with $\mathrm{T} 4$. This result was supported by Brudnicki et al. (2015) who reported that it should be pointed out that the data recorded for the greater body weight and a higher viability rate in the experimental group birds. Economic profit may come at the cost of reduced bird performance, health, and welfare if densities are excessive (Estevez, 2007).

\section{REFERENCES}

Abed, F.; Karimi, A.; Sadeghi, G.; Shivazad, M.; Dashti, S. and Sadeghi-Sefidmazgi, A. (2011): Do broiler chicks possess enough growth potential to compensate long-term feed and water depravation during the neonatal period? S. Afr. J. Anim. Sci. 41: 33-39.

Batal, A.B. and Parsons, C.M. (2002): Effects of age on nutrient digestibility in chicks fed different diets. Poult. Sci. 81: 400-407.

Batal, A.B. and Parsons, C.M. (2004): Utilization of various carbohydrate sources as affected by age in the chick. Poult. Sci. 83: 1140-1147.

Berri, C.; Godet, E.; Hattab, N.H. and Duclos, M.J. (2007): Effect of genotype and early nutrition on the number and activity of satellite cells in chicken Pectoralis major muscle. Archivfür Tierzucht 50: 32-33.

Bhanja, S.K.; Anjali Devi, C.; Panda, A.K. and Shyam Sunder, G. (2010): Effect of post-hatch nutrient intubation on performance, intestinal growth, meat yield and immune response in broiler chickens. Asian-Aust. J. Anim. Sci. 23: 515-520. 
Bigot, K.; Tesseraud, S.; Picard, M. and MignonGrasteau, S. (2003): Effects of delayed feed intake on body, intestine, and muscle development in neonate broilers. Poult. Sci. 82: 781-788.

Boersma, S.I.; Robinson, F.E.; Renema, R.A. and Fasenko, G.M. (2003): Administering oasis hatching supplement prior to chick placement increases initial growth with no effect on body weight uniformity of female broiler breeders after 3 weeks of age. J. Applied Poult. Res., 12: 428-434.

Brudnicki, A.; Szymeczko, R.; Bednarczyk, M.; Głowińska, B. and Pietruszyńska, D. (2015): Assessment of the effect of alpha-galactosides on yolk sac resorption rate in broiler chickens. The Journal of Animal \& Plant Sciences, 25(2): 2015, Page: 387-391

Cengiz, O.; Koksal, B.H.; Tatli, O.; Sevim, O.; Avci, H.; Epikmen, T.; Beyaz, D.; Buyukyoruk, S.; Boyacioglu, M.; Uner, A. and Onol, A.G. (2012): Influence of dietary organic acid blend supplementation and interaction with delayed feed access after hatch on broiler growth performance and intestinal health. Veterinární Medicína 57:515-528.

Dibner, J.J.; Knight, C.D. and Ivey, F.J. (1998): The feeding of neonatal poultry. World Poultry, 14, N0. 5.

Duffy, M. and Nanhou, V. (2003): Factors in the Success of Farms and the Relationship Between Financial Sucess and Perceived Sucess. Ames: Yowa State University, Staff General Research Papers.

Duncan, D.B. (1955): Multiple Range and Multiple Test. Biometrics, 11: 1-42.

El-Husseiny, O.M.; El-Wafa, S.A. and El-Komy, H.A. (2008): Influence of fasting or early feeding on broiler performance. Int. J. Poult. Sci., 7: 263271.

Estevez, I. (2007): Density allowances for broilers: Where to set the limits? Poult. Sci. 86:12651272.

Hooshmand, M. (2006): Effect of early feeding programs on broiler performance. Int. J. Poult. Sci. 5(12): 1140-1143.

Jiang, K.; Jiao, H.; Song, Z.; Yuan, L.; Zhao, J. and Lin, H. (2008): Corticosterone administration and dietary glucose supplementation enhance fat accumulation in broiler chickens. Br. Poultry Sci. 49: 625-631.

Juul-Madsen, H.R.; Su, G. and Sørensen, P. (2004): Influence of early or late start of first feeding on growth and immune phenotype of broilers. Br. Poult. Sci. 45: 210-222.

Leeson, S. and Summers, J.D. (2001): Nutrition of the chicken, 4th edition. M.L. Scott and Associates, Ithaca, N.Y. Pp. 41.

Mahmoud, K.Z. and Edens, F.W. (2012): Breeder age affects small intestine development of broiler chicks with immediate or delayed access to feed. Br. Poult. Sci. 53: 32-41.

Marcu, A.; Vacaru-Opriş, I.; Dumitrescu, G.; Ciochină, L.P.; Marcu, A.; Nicula, M.; Peţ, I.; Dronca, D.; Kelciov, B. and Mariş, C. (2013): The Influence of Genetics on Economic Efficiency of Broiler Chickens Growth. Animal Science and Biotechnologies, 46 (2).

Mendes, A.S.; Gudoski, D.C.; Cargnelutti, A.F.; Silva, E.; Carvalho, E.H.; Morello, G.M. (2014): Factors that Impact the Financial Performance of Broiler Production in Southern States of Paraná, Brazil. Brazilian Journal of Poultry Science.v.16 / n.1 / 113-120.

Mohebodini, H.; Dastar, B.; Sham-Sharg, M. and Zarehdaran, S. (2009): The comparison of early feed restriction and meal feeding on performance, carcass characteristics and blood constituents of broiler chickens. J. Anim. Vet. Adv., 8: 2069-2074.

Murakami, H.; Akiba, Y. and Horiguchi, M. (1992): Growth and utilization of nutrients in newly hatched chick with or without removal of residual yolk. Growth, Dev. Aging, 56, 75-84.

Nabizadeh, A. (2012): The effect of inulin on broiler chicken intestinal microflora, gut morphology, and performance, J. Animal and Feed Sci., vol. $21,725-734$.

Nir, I.I. and Levanon, M.M. (1993): Research note: effect of posthatch holding time on performance and on residual yolk and liver composition. Poult. Sci. 72: 1994-1997.

Nitsan, Z.; Dunnington, E.A. and Siegel, P.B. (1991b): Organ growth and digestive enzyme levels to 15 days of age in lines of chickens differing in body weight. Int. J. Poult. Sci. 70: 2040-2048.

Nitsan, Z.; Avraham, G.B.; Zoref, Z. and Nir, I. (1991a): Growth and development of the digestive organs and some enzymes in the broiler chick after hatching. Br. Poult. Sci. 32: 515-523

Noy, Y. and Sklan, D. (1998): Metabolic responses to early nutrition. J. Appl. Poult. Res. 7: 437-451.

Noy, Y. and Sklan, D. 1999): Different types of early feeding and performance in chicks and poults. J. Appl. Poult. Res. 8:16-24.

Noy, Y. and Uni, Z. (2010): Early nutritional strategies. World Poult. Sci. J. 66: 639-646.

Ozols, A. and Sheshukova, T. (1985): The role of the duodenum in adaptive changes in sucrose digestion in the small intestine of chicks. Comp. Biochem. Physiol., A, 80: 343-347.

Peebles, E.D.; Keirs, R.W.; Bennett, L.W.; Cummings, T.S.; Whitmarsh, S.K. and Gerard, P.D. (2005): Relationships Among Prehatch and Posthatch Physiological Parameters in Early Nutrient Restricted Broilers Hatched from Eggs Laid by Young Breeder Hens. Poult. Sci. 84: 454-461. 
Perić, L.; Milošević, N.; Žikić, D.; Kanački, Z.; Džinić, N.; Nollet, L. and Spring, P. (2009): Effect of selenium sources on performance and meat characteristics of broiler chickens, J. App. Poul. Res., vol. 18, 403-409.

Rammouz, R.E.; Said, S.; Abboud, M.; Yammine, S. and Jammal, B. (2011): Effect of Post-hatch Early Feeding Times Starter Supplemented with Egg Yolk and White of Boiled Chicken Eggs (Rhod Island Red) on Growth Performance, Viscera Development, and Immune Response in Broiler Chickens. Aust. J. Basic \& Appl. Sci. 5: 660-671.

Saki, A.A. (2005): Effect of post-hatch feeding on broiler performance. Int. J. Poult. Sci. 4: 4-6.

Shariatmadari, F. (2012): Plans of feeding broiler chickens. Worlds Poult. Sci. J. 68:21-30.

Sheshukova, T.A. and Ozols, A.Y. (1986): A shift towards sucrose in carbohydrate transport in the small intestine of chickens of various ages. Assimilyatsiya pitatel'nykh veshchestv V organizme zhivotnykh. 203-214.

Sklan, D. and Noy, Y. (2000): Hydrolysis and absorption in the small intestines of posthatch chicks. Poult. Sci. 79:1306-1310.

Sklan, D.; Noy, Y.; Hoyzman, A. and Rozenboim, I. (2000): Decreasing weight loss in the hatchery by feeding chicks and poults in hatching trays. J. Appl. Poultry Res. 9:142-148.

Sorbara, J.O.B.; Menten, J.F.M.; Longo, F.A.; Pedroso, A.A.; Racanicci, A.M.C.; Gaiotto, J.B.; Figueiredo, A.N. and Murakami, A.E. (2006): Allometric growth of the gastrointestinal tract of broilers from 1 to 7 day-old. EPC 2006 - 12Th European Poultry Conference, Verona, Italy.10-14.

Tabedian, S.A.; Samie, A.; Pourreza, J. and Sadeghi, G.H. (2010): Effect of Fasting or Post-Hatch Diet's Type on Chick Development Journal of Animal and Veterinary Advances. Year: 2010| Volume: 9 | Issue: 2 | Page No.: 406-413.

Tabedian, S.A.; Mehdi, T.; Mehrdad, M. and Alireza, $J$. (2011): Effect of fasting or post-hatch diet's type on performance of broiler chicks.
International Conference on Food Engineering and Biotechnology IPCBEE vol.9.

Tabler, G.T. (2008): Early feed intake and bird performance. AVIAN Advice, Vol. 5, University of Arkansas Cooperative Extension Service.

Ullah, M.S.; Pasha, T.N.; Ali, Z.; Saima, Khattak, F.M. and Hayat, Z. (2012): Effects of different pre-starter diets on broiler performance, gastro intestinal tract morphometry and carcass yield. The Journal of Animal \& Plant Sciences, 22(3): 2012, Page: 570-575.

Van, I. (2003): Growth and broilers industrialization. Ed. Ceres, Bucharest, pp.235-236.

Vargas, F.S.C.; Baratto, T.R.; Magalhães, F.R.; Maiorka, A. and Santin, E. (2009): Influences of breeder age and fasting after hatching on the performance of broilers. J. Appl. Poult. Res.18: 8-14.

Wang, A. (2014): The effects of different feeding program and inclusion of glycerol, glucose or sucrose in broiler starter diets on growth performance and intestinal development. Thesis Dalhousie University Halifax, Nova Scotia.

Wei, J.; Coon, C. and Swanson, B. (1984): Weight gain and feed efficiency of chicks fed sucrose fatty acid esters. Poult. Sci. 63: 378-380.

Willemsen, H.; Debonne, M.; Swennen, Q.; Everaert, N.; Careghi, C.; Han, H.; Bruggeman, Tona V.K. and Decuypere, E. (2010): Delay in feed access and spread of hatch: importance of early nutrition. World Poult. Sci. J. 66: 177-188.

Yue, L.; XiaoJing, Y.; Ying Dong, N.; Decuypere, E.; Buyse, J.; Everaert, N.; Grossmann, R. and RuQian, Z. (2012): Early-age feed restriction affects viability and gene expression of satellite cells isolated from the gastrocnemius muscle of broiler chicks. Journal of Animal Science and Biotechnology 3:33.

Zubair, A.K. and Leeson, S. (1996): Compensatory growth in the broiler chicken: a review. Worlds Poult. Sci. J. 52: 189-201.

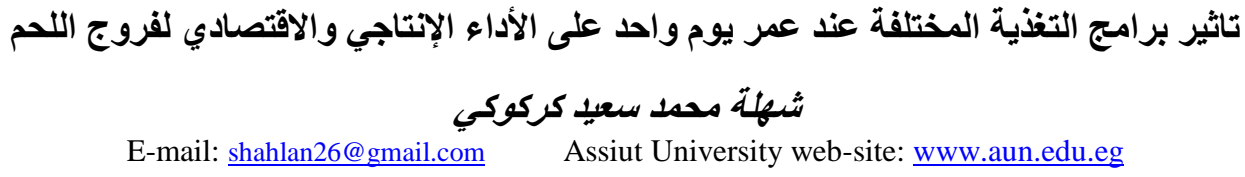

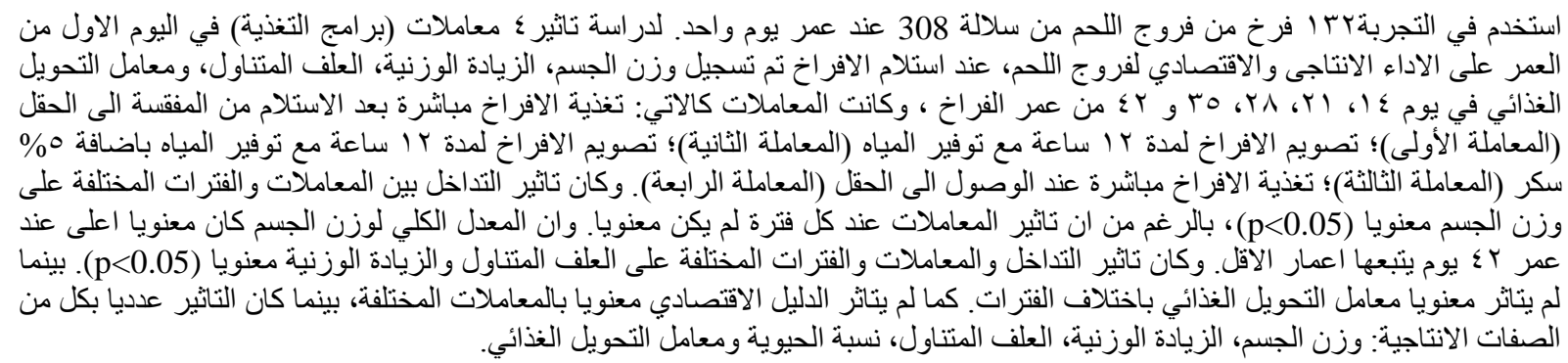

